\title{
4 \\ Social Remittances and the Disruption of Traditional Norms and Community Leaders
}

In chapter 3, I show how, in the face of critical shortages of basic public goods, refugees use digital spaces to reaffirm kinship (and kin-like) ties, reinforce Palestinian ahl and hamula 'adat wa taqlid, and inspire remittance flows from the diaspora. But while they may reinforce traditional social norms, ICTs also hold the potential to alter and undercut the very networks that they facilitate (Ramo 2016). ICTs may empower new actors, propel communities to redefine themselves, and undermine social norms. In fact, ICTs used by Palestinian refugees may generate a new space for dialogue that inspire what Peggy Levitt $(1998,2001)$ refers to as social remittances, or the flow of new ideas, values, and behaviors between and among diaspora and camp communities.

To borrow from Mohsin Hamid's observations in his magical-realist novel Exit West, ICTs allow for conversations that "might have never been and could never be" in the "real" world. It is unlikely that Palestinians living in isolated camps in the preinternet era would have been able to communicate in real time with those in the diaspora. Moreover, the wide availability of smartphones in the camps allows the younger generations of Palestinians to have discussions about their communal identity and expected norms out of earshot of traditional authority figures like religious elders or family patriarchs. Palestinians in the camps and those in the diaspora can debate, sometimes heatedly, taboo topics and reimagine the Palestinian community in a space that did not exist before the Internet. ICTs serve as a mechanism for the dynamic evolution of the village and family identity to reflect the new political challenges and opportunities confronting those inside the camp and in the diaspora. 
One Palestinian from the diaspora shared reflections from her 2017 diary on the new connections and ideas that digital interactions introduce.

The first time I "met" a Palestinian woman whose family had never left Jerusalem, who had lived there since long before 1948, was in an online digital chat room. She was talking about the challenges of traveling for her humanitarian work. I asked her how she was able to travel from Jerusalem to London as a Palestinian woman in 2017. She said, "Oh, because I have an Israeli passport. I get treated like shit at the airports and checkpoints, but still I can travel." She said, "What about you?" I said, "I am a documented refugee with UNRWA but also have an American passport and live in the US, so that is how I travel." She said, "Oh, so your family left in 1948?" I said, "Oh, yes." I felt shame that we had left and she had stayed. I don't know what she thought of me, of all of us who left and ended up in the camps. We acted kind of like distant cousins, unsure of how intimate we could be-her experience was so different than mine and my family. We felt so differently about many issues-one state or two states? She wanted one state, and I wasn't entirely convinced it would be the best for us. She felt all Palestinians could return to their old villages, that there was space, but I felt it was a pipe dream. Her Palestinian state was so different than the Palestinian state I envisioned. We were operating in two different worlds with two very different ideas about what our nation and state would look like. I felt I could not speak about this separateness to my family and to my village in the camps in Lebanon because it meant we were not, in fact, one with the Palestinians living over there [in the Occupied Territories]. We had been divided by history and time and real experience. I couldn't help but feel that those of us from the camps in Lebanon and Jordan and Syria and living in all the nooks and crannies of the rest of the world ... that we were building a distinct dream.

Her diary exposes the complexity of Palestinian identity. It also shows how the internet presents an opportunity to examine the shared norms and ideas that breed reciprocity and remittance flows, and at times, disrupt those connections among Palestinians living in different spaces. Levitt's $(1998,2001)$ study of the transnational diaspora from Miraflores, a village in the Dominican Republic, provides a helpful comparative case for making sense of the dynamic among transnational Palestinian refugees. To explore this tension, I used survey data from the Palestinian diaspora spanning the second, third, and fourth generations in Australia, North America, Europe, and the Arab Gulf states.

The data show that in addition to generating vital economic remittances, digital spaces introduce social remittances that create an altered sense of Palestinian political identity. The flow of social remittances in digital spaces generates controversies over communal gatekeeping and enforcement of norms. Engagement with digital technology changes the users of the technology and introduces unforeseen issues. When real-world norms bump against digital practices, the conflict may disrupt accepted modes of engaging with the community, especially with village and family elders. In one particular case, the enforcement of norms in the digital versus real world sparked a village conflict that threatened to undermine the flow of financial remittances. 


\section{UNDERSTANDING SOCIAL REMITTANCES}

Though the transnational migration literature focuses heavily on the flow of economic remittances, people also send and receive social remittances-ideas, behaviors, and values that flow across borders among transnational communities (Levitt 1998, 2001). Social remittances can help individuals embedded in a particular context and accustomed to a particular set of identities to imagine a new cartography with which to navigate the world (Appadurai 1990). For example, they can encourage people to try on new gender roles, experiment with new ideas about politics or religion, and adopt new forms of organization (Levitt 1998, 2001). Notably, Peggy Levitt and Deepak Lamba-Nieves (2010) argue that social remittances have a circular effect: the ideas and experiences that migrants bring from their country of origin strongly influence who and what they are exposed to in the country where they settle. In turn, these experiences affect the social remittances they send home. In Transnational Villagers (2001), Levitt traces the flow of social remittances from migrants living in the Jamaica Plains neighborhood of Boston, Massachusetts, to their home community of Miraflores in the Dominican Republic. She finds that social remittances have complex effects on transnational village networks.

It is important to unpack how social remittances work before extending the concept to Palestinian refugee communities interacting in digital spaces. Among Miraflorenos in both the sending and receiving countries, Levitt shows, social remittances have encouraged transnational cooperation and revitalized the way in which the community views itself. Traditional kinship connections have been reconfigured to meet the challenges of contemporary spaces. Specifically, Levitt finds that Dominican political parties like the Partido Revolucionario Dominicano (PRD) intentionally pattern themselves on the transnational family and village networks of Miraflorenos. The PRD operates via circulos de influencia, or "influence circles," of family members in the Dominican Republic and the United States, whom they call upon to make donations or attend party events. In effect, "non-Dominican citizens" like the migrants living in the Boston suburbs "are part of the party" (Levitt 2001, 137).

New ideas of how to connect with bureaucracy and influence political outcomes, based on experiences in the United States, have influenced people living in Miraflores, their connection to the PRD, and their views of local governance. About 50 percent of interviewees felt that the exchange of these new ideas between migrants and villagers at "home" on the island had had a positive net effect on sustained community connection and reciprocity, evidenced in financial flows to Dominican political and social institutions. In fact, PRD officials estimate that roughly 10 to 30 percent of the party operating budget comes from migrants, and 50 percent of campaigns are financed through transnational economic remittance flows (Levitt 2001, 149). Aside from strengthened transitional linkages, residents of Miraflores felt these new ideas generated demands for political alternatives to the status quo, particularly for more transparency and less local-level corruption. For example, one respondent said: 
I have never been to Boston, but my brothers say that the elections there are honest. Bill Clinton can't just tamper with votes because he wants to stay in power like Balaguer does here. In Santo Domingo, politics is a risk. Everything is personal. If I am from one party and you are from another's, we can't share with one another. We can't discuss things. There you can say what you think. During the last elections, my brother told me how Bush and Clinton in a certain TV program said things to each other, and at the end they shook hands and one felt that the things they said remained behind because it was a political thing. Here the same thing happens but after the TV program is over they go outside and fight. (Levitt 2001, 153)

Hearing about political alternatives from migrants prompted new ideas about political relationships at home: “There are greater demands for more democracy within the parties, that the judicial system should be separate from the executive branch which is so corrupt.... Emigration plays a role, since the people who come back come with these new ideas" (Levitt 2001, 153).

Hearing about the activism of Miraflorenos in Boston empowered those at home to reimagine their community's potential. One villager said, "We have begun to imitate US publicity. We use slogans, posters, bumper stickers. We didn't do this before. . . . Also, people are more likely to form groups now. Neighborhood associations, associations of certain kinds of producers and business owners. They learned this in the US, where they felt the need to come together, to work together, to not be so dispersed" (Levitt 2001, 154).

From this perspective, social remittances inspire the exchange of new ideas that trigger increasing reciprocity in the form of economic remittances and also reinforce the village identity and power. However, they can also challenge the basis for transnational village connections and cooperation. When new ideas undermine traditional power dynamics and norms of behavior, for better or worse, they can unravel the links between migrants and villagers. Roughly 35 percent of Miraflores residents feel that migrant ideas have had a negative effect on politics and relations at home. Levitt notes that "several respondents argued that migrants absorbed the worst aspects of American society and then modeled these for their friends and family" (2001, 152). One villager commented:

With respect to the development of a social or cultural consciousness, I see that each day we go from bad to worse. Things are very different than they were fifteen years ago, and I tell you this with a heavy heart. The youth of Miraflores don't think about a future. They are thinking about having fun, getting money to be able to drink beer and go out and dance, and some of them want to go out and get drugs. It is incredible the number of young men who smoke dope. It is the fault of those who live in the US, who go back and encourage their friends to get into this. You know that in Miraflores there is not one house that doesn't have someone living in the US. These kids have never had to work to get their food. They stand around on the corner with their friends. Idleness is the mother of all vice, and since they aren't going to school or work, they fall prey to these vices. (Levitt 2001, 153) 
These concerns echo the warnings and fears of the Amish community described in chapter 3. The spread of new ideas, behaviors, and customs that put the individual above or before the community's needs wreaks havoc on intergenerational relations in receiving communities, as younger folks drift toward new ideas. Certainly digital devices and the internet open up space for transnational interactions between younger generations.

Levitt argues that social remittances are generally transmitted through established sociopolitical or religious institutions, like the PRD, and through faceto-face interactions. Her research does not explicitly address the transmission of social remittances through digital spaces, though she recognizes the power of digital technologies: "New communication and transportation technologies permit easier and more intimate connections. These heighten the immediacy and frequency of migrants' contact with their sending communities and allow them to be directly involved in everyday life there in fundamentally different ways than in the past" (Levitt 2001, 24). Extending her study to Palestinian refugee networks in digital spaces permits exploration of how social remittances create both bridges and divides for transnational reciprocal action.

\section{AFFIRMING AND BUILDING TRANSNATIONAL RECIPROCITY THROUGH A SUBNATIONAL POLITICAL IDENTITY}

Supporting Levitt's assertion that social remittances can strengthen links between migrants and their "home" communities, my own survey data show that social remittances exchanged in digital spaces among Palestinian refugees strengthened transnational connections and encouraged a vibrant reimagination of the community's power. This, in turn, enhanced economic remittance flows.

One survey respondent commented: "The internet builds a bridge among the Palestinian communities, so it's a very good means to connect the Palestinian extended families by narrowing the distance between us, learning about each other's different lives and experiences, but still staying close in the face of differences" (S-20). This trend was especially evident with respect to political ideas exchanged between members of the Samoie village diaspora living in democratically governed countries and villagers still living in the camps. Palestinians using digital networks affirmed their political identity through family and village connections rather than established elite party politics. This is a distinct departure from how most scholarship on Palestinians represents their imagined political identity.

Loren Lybarger traces the downfall of the PLO-Fatah and the shift away from secular political identities in his careful study of Palestinian diaspora communities in Chicago. He notes that among older generations of Palestinian in exile, particularly prior to the 1990s, Palestinian secular identities held great sway. The 
Arab Community Center (ACC), or markaz, founded in 1972, served as a hub for communal activity. Its activities included instruction in the Arabic language, in Arab and Palestinian history and politics, and in activities like tatreez (traditional embroidery) and dabka (village folk dancing) that had become potent symbols of Palestinian identity. According to Lybarger, these activities replicated the way the PLO factions and their associated organizations in the Occupied Territories and in the refugee camps in Jordan and Lebanon raised national awareness and cohesion (Lybarger 2020, 65). However, since that time, there has been a decline in support for secular identities among Palestinians in Chicago, the markaz is no longer the hub of communal activity, and there is an shift toward increasing religiosity.

Recent scholarship discusses how diaspora exile communities have used the Muslim umma (community of faith) to subvert secular political conversations of the past and offer an alternative form of Palestinian political identity. Lybarger (2020) documents the ways in which the umma is being newly deployed to galvanize support for Palestinian justice among the Palestinian community in Chicago. This community has a long history of organizing (Cainkar 2006, 2007), and a multitude of Islamic organizations have emerged from it.

However, Lybarger astutely notes that there is an inherent tension between faith-based organizations and the priorities of Palestinian national liberation and justice. He recounts a conversation with Hatem Abudayyeh, executive director of the Arab American Action Network (AAAN), that explains this tension: "You can't say there's this transnational Islamic experience that we all have. Maybe it helps to organize across nationalities when people look at this concept of umma islamiya [the global Islamic community]. But there are very specific issues based on nationality. There are black issues; Mexican issues; Arab issues, beyond Islam. It liquidates the national question when you organize religiously." National identities and issues mediate religious orientations. Moreover, as Abudayyeh points out, "even if there can be overlap between secular and 'faith- based' organizing frameworks, at key junctures the religious focus contradicts the priorities of national [Palestinian] liberation" (Lybarger 2020, 188-89).

While my refugee respondents certainly emphasized the importance of zakat, or Islamic tithing, in motivating some of their financial decisions to send remittances (I-116L, I-120L), I found less recognition of religious organizations as significant in mediating and organizing political identity among young Palestinians. My survey respondents imagine a political future, shaped by the exchange of social remittances in digital spaces, that explicitly repudiates both secular and Islamist political parties. Palestinian villagers living in camps outside the OT and their transnational networks have generally low expectations and poor opinions of the elite Palestinian establishment embodied by the PLO and Hamas. This was especially evident in the new ideas and conversations exchanged between the members of the diaspora living in democratic countries and those in the camps outside the OT. This evidence of a general shift away from political parties might 
be interpreted as indicating the divisive or factional effects of social remittances in digital spaces. In fact, however, a turn toward discussions of the power and capacity of subnational identity for mitigating problems and solving collective dilemmas has increased transnational village and family communal cohesion, inspired reciprocity, and increased the likelihood of direct cash remittances to those Palestinians suffering most.

One Samoie villager living the United States said in her open-ended survey response: "I would never give money to or support the PLO or Hamas or any of those political parties. They are all corrupt. I feel that most everyone in Nahr al-Bared, unless they are already in the pocket of the party, feels the same way. We just cannot trust any of them. We have to rely on our village network-not a party" (S-43).

Another young Palestinian activist observed: "Listen, my family has historically had deep ties to the PLO. My uncle actually died fighting for them in the 1970s. He is a celebrated martyr. My father is still affiliated with PLO-Fatah, but I do not think many young people like me feel connection to the party in the same way. My community and the way I think about power and activism and reciprocity is not structured by an elite Palestinian political party. It is made up of the relations between myself, my extended family, and broader Samoie village connections. Our power is rooted in those kinship-based connections - not a formal political party!" (I-13oL).

Her father, sitting at the same table and enjoying a coffee with us during the interview, countered: "The PLO is trying to develop intergenerational connections across the camps and the diaspora, especially with the younger kids like my daughter. We have a website and a Facebook group now too!" (I-131L). His daughter retorted, "Babaaaa [Daaaaad], ... no one I know visits that Facebook page. Ha ha ha! We connect through the family and village in digital spaces" (I-130L).

While there is a shared subnational identity that hints at how a state might one day function, the question of that state's relationship to an existing Palestinian political party and to Israel-a one-state or two-state solution (see Lustick 2019 for more discussion on the topic) - is far from resolved among transnational Palestinian villagers.

Divides between those in the diaspora and those in the camps outside the OT and between older and younger Palestinians are evident. The father-daughter conflict over the relevance and structure of a Palestinian state led by elite parties like the PLO illustrates this tension. For example, a college student with family roots in Samoie village said in a survey response: "The older generation has trouble with new ideas about Palestinian identity. But I feel like the younger generation has somewhat integrated many diaspora ideas for the most part. This can be attributed to the use of devices such as phones and computers that keep them connected to other parts of the world on a social, cultural, and political scale. I don't think many young people think of the PLO as revolutionary anymore. We have moved 
onto thinking about Palestinian identity in a new way." The respondent continued: "Within this new generation, they already have incorporated new ideas into the way they think about or do things, whether the rest of the community knows it or not. This is especially obvious to me in how we talk and think about the twostate solution. Spoiler alert: the old ways of thinking about a two-state solution are dead" (S-45).

Though scholars like Ian Lustick (2019) and others no longer believe a twostate solution is viable (perspectives bolstered by Israel's recent move to annex the West Bank), the debate persists among the Palestinian community. Exchanges in digital spaces offer evidence of the tensions over Palestinian identity and state making. For example, though the two-state solution has long been seen as the accepted and acceptable political goal, some young people are entertaining the idea of a one-state solution and viewing the two-state solution as a political pipe dream. One interviewee commented: "Talking to my cousin online, I realized some of us are interested in a one-state solution to the crisis. We both agreed that demographically, Palestinians will represent a majority in that one state, and if the Americans really want democracy in Israel, well, then give them what they want, and let democracy work" (S-48). When asked whether these views are shared by village elders, an interviewee said, "I have no idea. I doubt it. The old people are still all about two states, and they just can't imagine living with Israeli Jews. I want a job, I want a life, I want to be able to travel-I can imagine living next to them, but let us make sure the political process will be a truly democratic one. One state would actually serve my interests more than a two state. I would never speak of this in public with elders, though; this is something I explore privately in my digital networks" (I-126L).

Some third- and fourth-generation Palestinians living in the West are careful to note that while they may share new ideas among themselves, especially with regard to moderation and diplomacy toward Israel, democratic politics, and secularism, they believe real-world village elders will enforce their notions of appropriate political views on the camp community, consistent with the norms of collective loyalty and self-sufficiency. One college-aged Palestinian American with parents who grew up in the camps said in an open-ended survey response:

I was born and raised in the United States, and therefore my lived experience is extremely different from much of my extended family. By being immersed in the US, my education, friends, political views, views on secularism are distinctively American. Where much of my family [over there] would be unwilling to support anything related to Israel, and hold very strong opinions on cooperation and a peaceful solution, I would say that I am much more in the middle, just because I've been exposed to so many people and ideas from immensely different perspectives. ... It is unlikely these ideas of mine would be incorporated because people over there on the ground experience the world differently and would not contest the established norms about Israel outside our community. (S-59) 
For younger people inside and outside the refugee camps, this deviance from older generations' sentiments is hardly surprising. Since the end of the 1993 Oslo Accords, the focus of the Palestinian elite political apparatus has been almost exclusively on people living in the West Bank and Gaza and their relationship to Israel. These young people from Nahr al-Bared and their transnational network have never known a time when elite Palestinian political entities cared about the community left in camps outside the OT. As Walid Khalidi observes, the decision of the PLO to "repudiate exile politics" was viewed as a wise strategy because it helped the party consolidate power (2006, 169-71).

Khalidi notes that this shift alienated Palestinian refugees living in the camps outside the OT and the wider diaspora. Amal Jamal (2005) considers the internal dynamics of the Palestinian political elite and their impact on the struggle to establish a viable Palestinian state in the West Bank and Gaza. Through a series of fascinating interviews, she uncovers how Yassir Arafat and the Fatah leadership sought to mobilize social forces like secular nationalist groups and Islamist movements while at the same time subverting them to shore up PLO-Fatah dominance. Again she shows that the central Palestinian struggle for statehood and community development revolves around elite party politics inside the OT. Palestinians living in camps in Lebanon, Jordan, and Syria and in the wider diaspora have been largely ignored.

Though Laurie Brand extends studies of state formation to the refugee camps and host countries of Lebanon, Jordan, and Syria, she nevertheless views the vibrancy of social and political life through the lens of nationalist party politics. She maintains that the PLO's ability to consolidate power varied in different regions because of the opportunities and constraints of host-country politics $(1988,224)$. Some countries, like Jordan after 1970, were more open to Palestinian integration or actively sought to co-opt refugees. This receptiveness reduced the PLO's power as a key vector for Palestinian identity for refugees living there. In these cases, the host state subsumed the nationalist parties. In Lebanon, by contrast, the PLO was able to exploit the country's sectarian weaknesses and refusal of tawtin to gain political leverage in the camps. Brand integrates Palestinian refugees outside the OT into her discussion of the challenges of state building, but the state-making endeavor still focuses on the actions of Fatah party agents.

Though scholars of Palestinian politics commonly acknowledge that the interests of Palestinians outside the OT have been neglected, there is little consideration of how these refugees might be creating an alternative pathway for community building, one that relies on village networks. New political ideas shared in digital spaces and garnered from diaspora experiences in democratic countries have profoundly shaped Samoie villagers' feelings about their own community's political will and capacity.

Jamal al-Hajj has emerged as an influential person on the Samoie village Facebook page. He grew up in Nahr al-Bared refugee camp, migrated legally, gained 
citizenship in Sweden, and currently lives in the city of Malmö. (In fact, a significant number of people from Samoie village live in Sweden: beginning with an early refugee migrant scout in the 1970s, many have engaged in chain migration through legal sponsorship and endogamous clan marriage.) Since 2014, al-Hajj has been an active member of Sweden's Social Democratic Party. He was recently reelected to another term as a parliamentary representative. In the style of the political circulos de influencia or "influence circles" of family members in the Dominican Republic and the US described by Levitt (2001), al-Hajj frequently posts videos and messages on the Samoie village Facebook page describing the campaign and election process in Sweden, his political platform, and what an honor it is to represent his Palestinian roots in Sweden's democracy.

In August 2018 he posted a video asserting that Sweden is a champion of democracy because it gives individuals a voice regardless of religion and gender. A large number of Samoie villagers living inside the camps and the wider diaspora "liked" the post and engaged in thoughtful conversations in the comment thread congratulating al-Hajj and expressing interest in how a Palestinian voice can be represented in Sweden. He also shared campaign posters and images of him campaigning and attending rallies with Swedes. His Facebook page affirms his transnational audience: he writes his posts in both Swedish and Arabic. He writes about his decision to "fight right-wing populism with equality" in Sweden and promotes ideas about combating climate change and supporting women's rights. Palestinian villagers in the camp demonstrated their pride in his success by reposting images of his recent election win. His activities have inspired younger people in the camp to reimagine their own power and ability to bring about change.

One interviewee commented:

To see a Samoie villager [like al-Hajj] find success and a political platform with democratic support reminds me that no matter what the world says, I am not a terrorist or a bad person incapable of helping myself and my community. It goes to show that someone like me can do good things and be in politics and not be corrupt. Normally you think Palestinian politics, and you think of corruption and sell-outs. But I don't think politics has to be that way for us. I spearheaded a cleanup of the cemetery in Nahr al-Bared and worked with the Islamic Relief Organization to do it. That organization relies on the funding from our own people living all over the world. I then mobilized a lot of young people to do the cleanup of our ancestors' graves, and we used the money transparently to improve our camp conditions to give us dignity in death. You know what?! This sounds like the beginning of Palestinian democracy to me! (I-117L)

Though Levitt (2001) demonstrates how the exchange of social remittances strengthened transnational bonds and led to increasing financial support of Dominican political parties and campaigns, my surveys and interviews show that Palestinian refugees rarely contribute to political parties. This finding deviates from typical conceptions of Palestinian nationalism. Many Palestinians 
outside the OT have no allegiance to Fatah-PLO or Hamas. Lybarger (2020) documents the failures of secular parties to muster broad support among the young generations of diaspora Palestinians in Chicago. In my interviews, one Palestinian living in Dubai said, "The financial support I share only goes to my family and village. The existing Palestinian political parties don't really care about people like my family in the camps in Lebanon" (I-126L). Instead, most members of the Palestinian diaspora were sending money to family and village networks. A member of the Samoie diaspora in the United States commented: "I would never give money to a political party in the refugee camps or in the OT, but seeing young people do good things like cleanups in the camp graveyard and doing civically minded activities documented on Facebook is something I can get behind. It is how a democracy should function, and our people are intuitively oriented toward this because we have always had our loyalty to serve others-our family and village community-above our personal gain. I send money to those kids doing good work in the camps. This is our village democracy at work" (I-114L).

Jamal al-Hajj also posts images of Swedish politicians, like the former representative Marie Granlund speaking out in support of Palestinians' right to self-determination on the anniversary of the Nakba on May 15, 2019. Upon seeing this, one refugee from the camp said in an interview response, "Seeing images of a Swedish politician supporting our cause and believing that we can have a better political future reminds me that we aren't all alone. When Jamal shares these images, it gives me the fuel to push for a better political community among Palestinians-not rooted in the corruption of elite parties but in a new vision of the future" (I-118L).

Among young Palestinians, any sense of a national identity or a moral duty to serve their people is mediated by digital village and family networks. One student at an elite university in America wrote in his survey response:

I really don't give a crap about religious and secular Palestinian parties. They have never done a single thing to change the lives of my family living in Nahr al-Bared. The only impetus for justice is motivated by my global village network. This network motivates the work for justice and sustains justice for the long term. I am not living in the camp today and I am at college right now because of this network. I know that my younger siblings will only make it out if that same network gets activated. For me, the heart of a future Palestine beats in the traditions and actions of the village. (S-47)

Ideas about the Nakba and how it should be represented in digital spaces provide additional examples of the flow and unifying effects of social remittances. Many Palestinian youth living in the diaspora make efforts to connect to their preNakba origins. Some have never lived in Palestine or a refugee camp. Some have only one Palestinian parent. Though they carefully note their "mixed" status, they still feel deeply connected to pre-1948 family and village frameworks. In the Facebook groups Post Colonial Memes for Oriental Minded Teens, which had 20,895 
members as of July 2018, and Halal Memes for Jannah Minded Teens, which had 158,460 members as of July 2018, there are myriad posts by young Palestinians living in North America and Europe that reflect on their pre-Nakba village identity. For example, around the time of annual national Nakba remembrances on May 15, members shared scanned images of their ancestral homes, images of great-grandparents, papers authenticating family members' service in the British mandate government, and family mementos. One poster noted that it was through her grandmother's stories and her grandfather's pictures that she felt connected to her pre-1948 village. She has never been to this village or lived in a refugee camp, but the family and village frameworks represent her boundaries of an imagined home. Again, national identity is mediated through a subnational identity and network.

Palestinians living in North America, Europe, and Australia also post on camp village Facebook pages. Of the Palestinian diaspora members I interviewed, some were born in Palestine prior to the Nakba, some were born in the refugee camps and migrated to the West, and several were born in third countries of resettlement. For most respondents, one or both of their parents were born in Palestine or in Nahr al-Bared or another refugee camp and had migrated to the West for economic opportunity. At home, many spoke Arabic with their parents, though three respondents spoke only English in their homes. One respondent felt her primary language was Spanish because her mother was of Latino descent, and she rarely spoke Arabic with her father (S-28).

One woman noted: "Even though I was born and raised in the US with an American mother, a large part of my cultural identity is Palestinian because I grew up around my father's Palestinian side of the family." Her father's family was originally from Samoie village, but she has family living in Nahr al-Bared and the Zarqa refugee camp in Jordan. She had visited the refugee camps only a handful of times, but she stayed connected to her relatives in the camps primarily through platforms like Facebook, where she learned of family weddings, births, graduations, and deaths. She commented: "Being in the Northeast of the US has made me a little isolated from my family. Seeing what they are up to on Facebook village pages reconnects me to them and can, if only briefly, remove that feeling of isolation. Having internet platforms to learn about people's daily lives in the camps has also helped me empathize with my family in the camps more" (S-26).

One Palestinian who is very active on village, family, and Palestinian social media wrote about how he feels when he engages with others online: "I feel empathetic and more connected to my people, and to all other people who share the common experience of collective or individual suffering as a result of injustice. Whether it's the Palestinians suffering under the Zionist regime, or Egyptians who are living in the diaspora due to the dictatorship, etc. I also feel encouraged to take part in efforts to ease the suffering of those who face such injustices, through volunteering in relief and social justice efforts." He also noted: "I have a master's 
in environmental engineering, and my primary interest is in creating accessible sustainable technologies that could be used in refugee camps. Conversations with my family over there [in the camps] reveal that people are, in fact, hungry to improve their conditions and believe in climate change too" (S-23).

Digital conversations about the injustices experienced in the camps and the OT have inspired real-world political activism among young people living in the diaspora in democratic countries. Social remittances have inspired virtuous circles of activism and transnational village connections. For example, descriptions of injustices "over there" have spurred protests over immigration and asylum policies in the United States. One respondent wrote:

Every year when the anniversary of the Nakba rolls around, I feel really angry, and hearing all these stories of loss and sadness and the trauma of people stuck in the camps day in and day out moves me to do something. I go to protests in Houston, and I am an active organizer in the Houston Palestinian festival. I was just at a protest over the Palestinian refugee student who was initially denied entry into the United States as he was about to enter school at Harvard. That was some salty racist crap to deny a refugee entry when he was already accepted into Harvard. I want our Palestinian voice represented in the American political landscape too. (S-42)

One Samoie villager, who has a daughter who was born and raised in the United States, said:

These young teenagers protest in the United States in support of Palestinian refugee family living in the camps. For the younger generation that has grown up here [in America], protesting is normal and safe, and they still feel a direct line to the trauma of the Nakba. You cannot watch young children imprisoned for throwing a stone or see your grandfather's desecrated grave and not feel emotionally moved. They have melded the best of American democratic values with their ahl and hamula loyalties. We can sustain our global community of refugees if these young people here in America and in Nahr al-Bared continue on like this. (I-120L)

For the transnational Palestinian community, digital spaces spur the flow of social remittances that strengthen connections, generate economic remittances, and affirm a transnational political identity rooted in $a h l$ and hamula identity.

\section{DIGITAL AND REAL-WORLD GATEKEEPER TENSION}

While digital spaces foster a strong sense of identity and community among Palestinians in the camps and the diaspora, these spaces also give rise to new forms of tension and division. My research suggests that the most divisive aspect of digital interactions is not the introduction or presence of new ideas, which will always diffuse into communities by one means or another, but rather the way digital interaction complicates claims to authority. Before ICTs, sheiks and patriarchs were the gatekeepers of Palestinian communal norms, and they controlled 
the spaces in which people interacted. Today, digital spaces are mostly filled with younger generations of Palestinians, who can interact without interference from these real-world gatekeepers. In effect, digital spaces give rise to a new generation of digital gatekeepers whose online interactions can challenge and ignore norms of honor and shame and change the very nature of the community, its views on reciprocity, and enforcement of those codes (Ramo 2016).

The tension between real-world village elders and digital message board managers was evident in an incident that unfolded in Nahr al-Bared during the spring and summer of 2019. A young Palestinian women from Samoie village posted a plea for scholarship assistance to complete her postgraduate studies. Several thousand dollars flowed in from extended family in North America and Eastern Europe, enabling her to fully fund her last year of college.

In response to the outpouring of financial support; the woman engaged in the common digital practice of publicly thanking and "tagging" individual Facebook members who sent remittances on the communal Facebook page. This gesture could be viewed as a tool for enforcing communal expectations by spotlighting the good behavior of reciprocators and provocatively shunning those who did not contribute. However, the cross-currents of the norms of digital spaces and those of the real world created unanticipated tensions when some older reciprocators in the diaspora learned of the public post of gratitude from younger relatives active on Facebook.

First, for many of the older people, the identification of those who sent money (and, by implication, those who did not) was viewed as immodest and brash, an affront to the practice of more subtle forms of social pressure. Second, some felt it was against Muslim humility to thank specific supporters and not others. They saw the decision to give money as a village obligation, connected to the Muslim practice of charity as coming from the heart, not a means of satisfying one's ego with a public shout-out. Third, the woman's decision to thank people by tagging them on Facebook meant that she omitted to acknowledge those who had supported her but were not active on Facebook. This prompted discord when some reciprocators assumed that others had not given money. Though one man living in Washington, DC, gave several thousand dollars, he was not active on Facebook, so he was not tagged or publicly thanked. He recalled:

It was quite embarrassing to learn of the post. It was not appropriate for her to name some people and not all the people. Frankly, I am 75 and not on Facebook, and I don't want to be publicly thanked. I don't get this whole tagging thing anyways. But what happened was that one person who was on Facebook and gave money called me and asked why I hadn't given any, since I was not mentioned in the post. I had to explain that I did give money. But there was lots of questioning, and I felt that people questioned my integrity and honor. I always give without expectation of public thanking, but I definitely don't want to be publicly shamed when I did, in fact, give. It created lots of unwelcome drama and leaves a bad taste in your mouth. 
It makes it harder to want to support the community financially when you get all this drama. (I-122L)

The young woman was unaware that engaging in what was, to her, the normal practice of thanking and tagging people on Facebook might disrupt traditional norms of honor, communal loyalty, and shame. The Facebook page manager never intervened to delete the post because it was considered "normal" online behavior to tag and thank friends and family on Facebook. To resolve the dilemma, the young woman was urged by her father and grandfather to edit her post and place phone calls thanking every single donor.

The example illustrates the broader tensions that technology introduces to networked refugees. Even in the complex example above, digital posts inspired reciprocal actions and economic remittances to fund a young woman's education. Yet in this digital interaction, the very norms and understandings of appropriate and inappropriate cooperation and behavior were tested and challenged. As one interviewee commented, "After an experience like the drama we just had, who would want to give money again in the future?" Indeed, in the long run these digital interactions may introduce enforcement challenges and dramas that upend the very village and family networks necessary for sustaining reciprocity and community survival amid catastrophic conditions.

\section{CONCLUSION}

The power of digital spaces has been creatively harnessed by the Samoie community. They have created a high-context digital space where shame is used to enforce cultural and historically relevant norms of collectivism, loyalty, and honor. Economic remittances are not the only resource exchanged via ICTs. Diaspora community members engage in the circular transfer of social remittances-ideas, behaviors, and values that flow across borders among transnational communities.

Like the members of the transnational village of Miraflores described by Levitt (1998, 2001), transnational Palestinian villages have witnessed increasing social remittance flows between the diaspora and residents of the refugee camps. Digital spaces offer opportunities for Palestinian villagers to engage in new ways with political elites and state systems. The experience of a Samoie villager campaigning and winning elections in a Swedish parliamentary democracy has inspired young Samoie villagers in Nahr al-Bared to imagine forms of transparent, representative, and democratic political engagement that differ greatly from the elite party politics embodied by Fatah-PLO and Hamas. These forms of social remittances draw the community closer to outsiders and establish a transnational collective identity that underscores the importance of reciprocity.

At the same time, engagement with the technology changes the users and drives wedges between different generations of the transnational village through 
the introduction of new communal gatekeepers in digital spaces. Small conflicts between real-world and digital communal gatekeepers increase the potential for upending the very network of reciprocity that has helped the community weather the challenges of a protection gap. In the long run, these digitally generated problems could severely disrupt the norms and networks necessary to fund vital goods and services. Yet despite the tensions that social remittances may cause in digital spaces, it seems that the core Palestinian ahl and hamula identity, with flexible notions of collectivism, honor, loyalty, steadfastness, and shame, may very well adapt to overcome the tensions introduced by new technologies and new flows of social remittances. 